Research Article

\title{
Formulation and Antibacterial Activity of Liquid Soap Containing Ketapang (Terminalia catappa L.) Leaves Extract
}

Asiska Permata Dewi ${ }^{*}$
Dini Mardhiyani ${ }^{2}$
1Department of Pharmaceutical and
Food Analysis, Universitas Abdurrab,
Pekanbaru, Riau, Indonesia
2Department of Pharmacy, Universitas
Abdurrab, Pekanbaru, Riau, Indonesia
*email: asiska.permata@univrab.ac.id
Keywords:
Antibacterial activity
Ketapang
Liquid soap
Phytochemical screening
Physical evaluation

\begin{abstract}
Ketapang (Terminalia catappa L.) is traditionally used by the community to treat the skin's infections caused by bacteria or fungi. In this study, T. catappa leaves extract was added to the liquid soap formula as an antibacterial. The purpose of this study was to determine the secondary metabolite compounds contained in $T$. catappa leaves extract, physical evaluation of the preparation, and antibacterial activity of liquid soap. Liquid soap formula was made with various concentrations of T. catappa leaves extract F0 (0\%), F1 $(1 \%), F 2(2 \%)$, and F3 (3\%). The resulting soap was evaluated for organoleptic, $\mathrm{pH}$, high foam, homogeneity, irritation, and its activity against Staphylococcus aureus, Staphylococcus epidermidis, and Escherichia coli using the disc diffusion method. The results showed that the $T$. catappa leaves extract contained flavonoids, tannins, saponins, and triterpenoids. The liquid soap formula F0 was clear, while F1, F2, and F3 had the characteristics of brown-dark brown, homogeneous, $\mathrm{pH}$ between 4.6-5.2, foam stability between $67-72 \%$, which was not significantly different and stable after five minutes of testing, and it did not irritate the skin. Terminalia catappa leaves extracts liquid soap has antibacterial activity at a concentration of $1 \%, 2 \%$, and $3 \%$, with the largest inhibition zone diameter produced by $S$. aureus.
\end{abstract}

Received: August 19th, 2020

Accepted: November 23rd, 2020

Published: February 28th, 2021

\section{INTRODUCTION}

Soap is a cleanser because it can remove dirt that sticks to parts of the body ${ }^{1}$. The use of liquid soap is more attractive to the public than solid soap because it is more practical, economical, not contaminated, easy to carry, and easy to store ${ }^{2}$. There have been many antibacterial soaps circulated in the market under various brand names.

Most of the antibacterial soap in the market still contains synthetic ingredients such as sodium lauryl sulfate (SLS) and triclosan, which have adverse effects on human skin. These side effects include sensitivity to the skin and turning off the protective layer on the skin to be more susceptible to exposure to harmful bacteria on the skin ${ }^{3 / 4}$. One of the efforts to overcome this problem is to utilize plants with antibacterial properties, one of which is ketapang (Terminalia catappa L.).

Terminalia catappa comes from the Combretaceae family, which is a large tree ${ }^{5}$ that has horizontal branches with several levels, leaves of 15-25 cm long and 10-14 cm wide ${ }^{6}$. This plant is widely distributed in countries with tropical and sub-tropical climates, especially in coastal areas ${ }^{7}$. Terminalia catappa are often found on roadsides as decoration and shade trees ${ }^{8}$. Terminalia catappa shed their leaves every day, and most of them fall during the dry season ${ }^{9}$. 
Terminalia catappa is known as a plant with pharmacological effects and is used traditionally ${ }^{6}$. In Asian countries, T. catappa leaves are usually used to treat dermatitis, hepatitis, diarrhea, and paresis. This plant is also included in the type of vegetable in the Caribbean, where T. catappa leaves are used in decoction to treat ulcers and urinary tract infections ${ }^{7}$. In India, T. catappa leaves are attached to the skin to treat scabies, leprosy wounds, and other skin diseases. Besides, in Malaysia, $T$. catappa leaves are used to treat diarrhea and fever ${ }^{10}$.

Terminalia catappa has shown biological effects such as having antibacterial and antifungal activities,11, antioxidants $^{12}$, antipyretic, hemostatic, hepatitis ${ }^{5}$, antiinflammatory, antidiabetic, antioxidant, hepatoprotective, and anticancer ${ }^{13,14}$, antiprotozoal, antiviral, anti-diarrhea, analgesic, antimalarial, and anticancer activities ${ }^{15}$.

Terminalia catappa leaves are known to contain chemical compounds such as tannins and flavonoids, which are thought to have antibacterial properties such as Aeromonas hydrophila, Escherichia coli, and Staphylococcus aureus ${ }^{11}$. Terminalia catappa also contains flavonoids, alkaloids, tannins, triterpenoids, steroids, resins, saponins, quinones, and phenolics ${ }^{16-18}$.

According to several previous studies, giving T. catappa leaves extract has been shown to inhibit of several bacteria such as Aeromonas salmonicida, A. hydrophila, E. coli $^{19}$, S. aureus, Pseudomonas aeruginosa ${ }^{5}$, and Bacillus amyloliquefaciens ${ }^{11}$. Terminalia catappa leaves extract also has antifungal activity against Candida $s p^{10}$. In addition, $T$. catappa leaves extract can be used to increase the resistance of betta fish and tilapia to A. hydrophila ${ }^{20}$.

In this study, the T. catappa leaves used were fallen leaves. Previous studies have shown that antibacterial and antifungal activity is higher in fallen T. catappa leaves than leaves still on trees ${ }^{21}$. Then the leaves are extracted with ethanol solvent and formulated into liquid soap.
Subsequently, physical evaluation and antibacterial activity were carried out. This study expects that the liquid soap products produced have good physical characteristics and antibacterial activity.

\section{MATERIALS AND METHODS}

\section{Materials}

The materials used were T. catappa leaves, 96\% ethanol, SLS, Comperland, CAB 30, NaCl, citric acid, glycerol, nipagin, Na4 EDTA, distilled water, blank disc, strains of S. aureus, S. epidermidis, and E. coli, antibacterial body wash soap, and Mueller-Hinton agar (MHA) media. The tools used were rotary evaporator, analytical scale, $\mathrm{pH}$ meter, incubator, autoclave, oven, caliper, and laminar airflow.

\section{Methods}

\section{Sample collection}

Terminalia catappa leaves were collected in Pekanbaru city and determined at the Botanical Laboratory, Universitas Riau. Samples taken were T. catappa leaves that had fallen around the trees with brownish leaves characteristics. The leaves of T. catappa were shown in Figure 1.

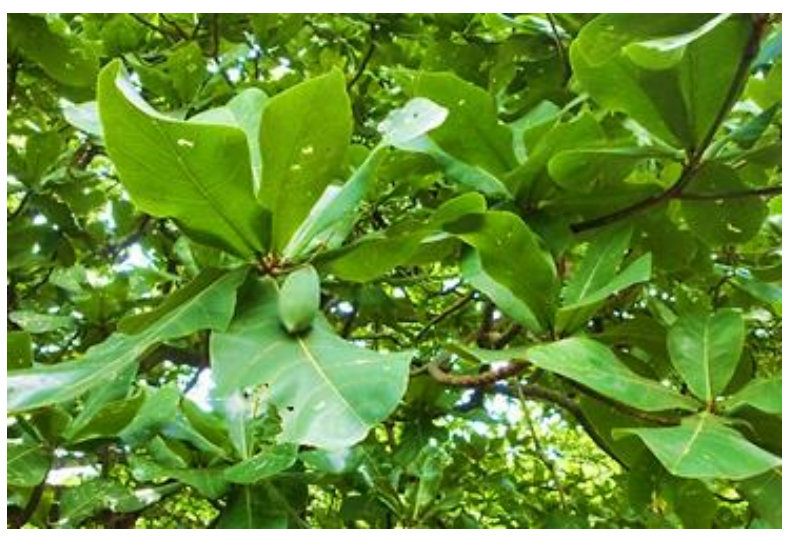

Figure 1. Terminalia catappa leaves

\section{Preparation of simplicia}

The collected leaves were washed under running water to remove dirt on the leaves. The leaves were then chopped into small pieces to expand the surface and speed up the drying process. The samples were dried at 
room temperature until dry; then, they were sorting and ground into a powder. The powders that had been produced were macerated with $96 \%$ ethanol for three days. Afterward, they were filtered and separated between the filtrate and the residue. Maceration was repeated three times with the same type and amount of solvent; then, the macerate was collected and evaporated using a rotary evaporator.

\section{Phytochemical screening}

1. Alkaloids test: A total of $0.5 \mathrm{~mL}$ of the sample was inserted into three test tubes. Each tube was then added by a few drops of Wagner's, Mayer's, and Dragendorff's reagents.

2. Flavonoids test: $\mathrm{A}$ total of $0.5 \mathrm{~mL}$ of sample was heated for five minutes, then it was added with three drops of $\mathrm{HCl}$ concentrated and a little $\mathrm{Mg}$ powder.

3. Saponins test: A total of $1 \mathrm{~mL}$ of sample was added with $2 \mathrm{~mL}$ of hot water, shaken, and let stand for five minutes.

4. Tannins test: A total of $0.5 \mathrm{~mL}$ of sample was added with three drops of $1 \% \mathrm{FeCl}_{3}$.

5. Terpenoids test: A total of $0.5 \mathrm{ml}$ of sample was added with three drops of Liebermann-Burchard's reagent through the test tube wall, and the results were observed 2223 .

\section{Liquid soap formulation}

As much as $40 \mathrm{~g}$ of Comperland was mixed with $30 \mathrm{~g}$ of CAB 30 and shook until it was thick. Then, $180 \mathrm{~g}$ of SLS was added along with $100 \mathrm{~mL}$ of water; then, it was stirred until blended. A total of $1 \mathrm{~g}$ of Na4 EDTA, $1 \mathrm{~g}$ of nipagin, and $400 \mathrm{~mL}$ of water were added and stirred until it was homogeneous. After it, $20 \mathrm{~g}$ of glycerin, $6 \mathrm{~g}$ of $\mathrm{NaCl}, 2 \mathrm{~g}$ of citric acid, and the remaining water were added and stirred until it was homogeneous. The mixture was stored in a tightly-closed container and waited until the shower gel's foam was gone. Furthermore, T. catappa leaves extract was added with a concentration of $1 \%, 2 \%$, and $3 \%$, stirred until it was homogeneous, and stored in a tightly closed container.

\section{Physical evaluation of preparations}

1. Organoleptic test: An organoleptic test was carried out by observing the physical form of liquid soap preparations using the senses. Liquid soap preparations that have been formulated were observed in terms of color, odor, as well as dosage form ${ }^{24}$.

2. $\mathrm{pH}$ test: Measurement of $\mathrm{pH}$ values was carried out using a $\mathrm{pH}$ meter in a 10\% sample solution, which was made by dissolving $1 \mathrm{~g}$ of the sample in $9 \mathrm{~mL}$ of water. Measurements were made by immersing the $\mathrm{pH}$ meter electrode, rinsed with distilled water into the solution. The $\mathrm{pH}$ value was determined after the numbers read on the $\mathrm{pH}$ meter have stabilized ${ }^{25}$.

3. Foam stability test: The sample was weighed as much as $1 \mathrm{~g}$, put into a test tube, then added with up to 10 $\mathrm{mL}$ of distilled water, shaken by turning the test tube back and forth, and immediately measured the level of foam produced. Then, the tube was left to stand for five minutes, then the height of the resulting foam was measured again after five minutes ${ }^{26}$.

$$
\text { Foam stability }=\frac{\text { final foam height }}{\text { initial foam height }} \times 100 \%
$$

4. Skin irritation test: Testing was done using an open patch test. The open patch test was performed by applying the preparation to the inner forearm. A total of $1 \mathrm{~cm}$ of the preparation was applied and observed for 30-minute intervals for skin irritation, erythema, and redness. It was tested on the four formulations that have been made.

5. Homogeneity test: A total of $1 \mathrm{~g}$ of liquid soap preparation was smeared on the surface of the mica plastic, then the coarse particles were observed by being touched, and the texture of the preparation was observed. 


\section{Antibacterial activity test}

All test bacteria (S. aureus, S. epidermidis, and E. coli) were respectively inoculated on MHA media. The $6 \mathrm{~mm}$ blank disc was dipped in liquid bath soap of T. catappa leaves extract and placed on the media's surface. The same thing was done with liquid bath soap sold in the market as a positive control and liquid soap base as a negative control. All samples were incubated at $35 \pm 2^{\circ} \mathrm{C}$ for 24 hours, and the formed inhibition zone was observed ${ }^{27}$. The interpretation was performed by looking at the clear area around the disc, indicating no bacterial growth. Then, the diameter of the clear zone formed was measured by using a caliper.

\section{RESULTS AND DISCUSSION}

\section{Phytochemical screening}

Phytochemical screening was carried out to determine secondary metabolite compounds contained in a plant. Secondary metabolite compounds in one type of plant could vary, influenced by climate, soil, temperature, humidity, and others ${ }^{28}$. Therefore, this phytochemical screening was carried out to determine the secondary metabolite content of $T$. catappa leaves growing in the Pekanbaru area. Based on the test results, the compounds in the ethanol extract of T. catappa leaves were flavonoids, triterpenoids, saponins, and tannins, as shown in Table I.

Table I. Phytochemical screening of T. catappa leaves extract

\begin{tabular}{cllc}
\hline No & $\begin{array}{c}\text { Phytochemical } \\
\text { test }\end{array}$ & \multicolumn{1}{c}{ Result } & Conclusion \\
\hline 1 & Alkaloid & white color & - \\
& - Mayer's & yellow color & - \\
& - Wagner's & brown color & + \\
2 & - Dragendorff's & $\begin{array}{l}\text { Flavonoid } \\
\text { orange color }\end{array}$ & + \\
3 & Triterpenoid/ & $\begin{array}{l}\text { purple color } \\
\text { blue color }\end{array}$ & + \\
& Steroid & $\begin{array}{l}\text { green color } \\
\text { stable froth or } \\
\text { foam is formed }\end{array}$ & + \\
5 & Tannin & Saponin & \\
\hline
\end{tabular}

\section{Physical evaluation of preparations}

The liquid soap preparation formulation was made with four formulas, where F0 was a liquid soap base, $\mathrm{F} 1$ = base
$+1 \% T$. catappa leaves extract, $\mathrm{F} 2=$ base $+2 \% T$. catappa leaves extract, and $\mathrm{F} 3=$ base $+3 \%$ T. catappa leaves extract. Physical evaluation of liquid soap preparations on the organoleptic test includes color, odor, and shape. Based on the color of the preparations formed on the base, F0 was clear, while F1 was brown, and F2 and F3 were dark browns. This was because the T. catappa leaves extract was brown. While the preparation's odor had a distinctive aroma of extracts, F0, F1, and F2 were thick, while F3 was slightly liquid. The more the addition of the extract causes the soap to become more liquid. The resulting soap preparations could be seen in Figure 2 .

Furthermore, evaluation of the preparations was carried out, including organoleptic tests, $\mathrm{pH}$, foam height, irritation, and homogeneity, as shown in Table II. The $\mathrm{pH}$ formed in liquid soap preparations ranges from 4.6 to 5.2. The SNI 4085:201729 stipulates that the $\mathrm{pH}$ quality requirements for liquid soap range from 4 to 10 so that all formulas produced have a $\mathrm{pH}$ value that meets the requirements as liquid soap. Furthermore, in the homogeneity test, the preparation was mixed homogeneously, and there were no coarse grains on the preparation.

Foam formation was not required and had little effect on the cleaning process, but it was more likely to patient acceptance of the product. The criteria for good foam stability, which was within 5 minutes, the foam stability obtained ranges from 60 - 70\%. In this case, F0, F1, F2 had met the criteria for good foam stability, which was in the range of $67-70 \%$, except for F3.

In the irritation test, the preparations were given to ten panelists who did not have a history of allergies. The preparation was applied to the skin of the forearm and left for 30 minutes. The test results showed no signs of skin irritation in the ten participants, such as dry skin, pain, bleeding, and cracked skin. Thus, the preparation was declared not to irritate the skin. 


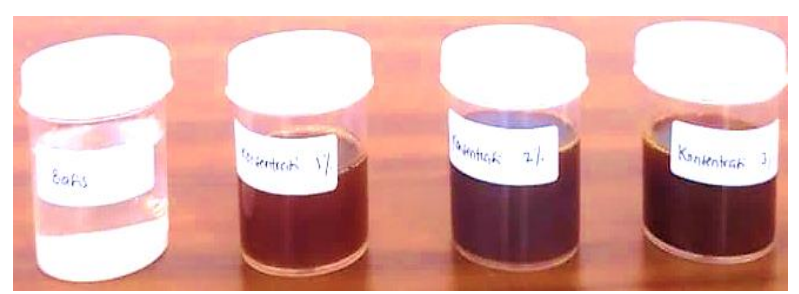

Figure 2. Liquid soap from T. catappa leaves

Table II. Physical evaluation of liquid soap from T. catappa leaves extract

\begin{tabular}{|c|c|c|c|c|}
\hline Parameters & F0 & F1 & F2 & F3 \\
\hline Color & Clear & Brown & $\begin{array}{l}\text { Dark } \\
\text { brown }\end{array}$ & $\begin{array}{l}\text { Dark } \\
\text { brown }\end{array}$ \\
\hline Odor & Odorless & $\begin{array}{l}\text { Distinctive } \\
\text { of extracts }\end{array}$ & $\begin{array}{l}\text { Distinctive } \\
\text { of extracts }\end{array}$ & $\begin{array}{l}\text { Distinctive } \\
\text { of extracts }\end{array}$ \\
\hline Shape & Thick & Thick & Thick & $\begin{array}{l}\text { Slightly } \\
\text { liquid }\end{array}$ \\
\hline $\mathrm{pH}$ & 5.2 & 5 & 4.8 & 4.6 \\
\hline $\begin{array}{l}\text { Foam } \\
\text { stability }\end{array}$ & $70 \%$ & $67 \%$ & $70 \%$ & $72 \%$ \\
\hline Irritation & $\begin{array}{l}\text { Nothing } \\
\text { happened }\end{array}$ & $\begin{array}{l}\text { Nothing } \\
\text { happened }\end{array}$ & $\begin{array}{l}\text { Nothing } \\
\text { happened }\end{array}$ & $\begin{array}{l}\text { Nothing } \\
\text { happened }\end{array}$ \\
\hline
\end{tabular}

\section{Antibacterial activity test}

The antibacterial activity test of T. catappa leaves extracts liquid soap was carried out on three formulas, two controls with three times replication against the bacteria S. aureus, S. epidermidis, and E. coli. The test results showed that the preparation could inhibit bacterial growth. The higher the addition of $T$. catappa leaves extract concentration, the larger the inhibition zone's diameter, as presented in Table III.

The antibacterial activity test of liquid soap preparations showed a difference in the inhibition zone diameter. The higher the concentration of T. catappa leaves extract was added, the higher the formed inhibition zone's diameter. Thus, the higher the ability of an extract to inhibit bacterial growth. This finding was due to the presence of flavonoid compounds in the extract, which could be antibacterial $^{30}$. This literature also supported by the results of phytochemical screening of T. catappa leaves extracts that were positive for flavonoid compounds.

The inhibition zone formed at each concentration of $1 \%$; $2 \%$; $3 \%$; positive; and negative control on S. aureus bacteria was 25.1; 28.13; 30.07; 40. 67; and $6.1 \mathrm{~mm}$, respectively. The inhibition zone formed on S. epidermidis bacteria at each concentration was 12.17; 15.13; 19.17; 25.1; and $6.17 \mathrm{~mm}$. Meanwhile, the inhibition zone against $E$. coli was 6.6; 7.17; 8; 15; and $6.2 \mathrm{~mm}$.

The variation of inhibition zone diameter and SD values ( $>1 \mathrm{~mm}$ ) yielded from three replications, which could be seen in Table III, was possibly generated by several factors such as the incubation temperature, diffusion ability of the extract, and volume of the medium used. The optimal temperature for bacterial growth is $35^{\circ} \mathrm{C}$; hence, the lower temperature used could produce variation in inhibition zone diameter. If three or more discs were arranged in one pile in the experimental study, the middle disc would experience incubation temperature below $35^{\circ} \mathrm{C}^{31}$.

Table III. Antibacterial activity of liquid soap from T. catappa leaves extract

\begin{tabular}{cccc}
\hline \multirow{2}{*}{ Sample } & \multicolumn{3}{c}{ Inhibition zone diameter \pm SD $(\mathbf{m m})$} \\
\cline { 2 - 4 } & S. aureus & S. epidermidis & E. coli \\
\hline Control $(+)$ & $40.67 \pm 1.15$ & $25.1 \pm 1.31$ & $15 \pm 0.85$ \\
F0 & $6.1 \pm 0.17$ & $6.17 \pm 0.29$ & $6.2 \pm 0.2$ \\
F1 & $25.1 \pm 0.96$ & $12.17 \pm 0.87$ & $6.6 \pm 0.53$ \\
F2 & $28.13 \pm 0.61$ & $15.13 \pm 1.27$ & $7.17 \pm 0.31$ \\
F3 & $30.07 \pm 1.01$ & $19.17 \pm 0.76$ & $8 \pm 1.25$ \\
\hline
\end{tabular}

Moreover, variation in inhibition zone diameter of bacterial growth also could be produced from the inconsistency of medium thickness used. The most effective medium thickness for bacterial inhibition study was approximately $4 \mathrm{~mm}$ thick, which thinner medium could quicken the extract solution diffusion while a thicker medium could slow it down ${ }^{32}$. Unfortunately, in this research, the medium thickness used was not measured; hence, it was pretty hard to make sure the medium thickness.

Based on the formed inhibition zone, it could be grouped into four groups; which were very strong (the inhibition zone >20 mm), strong (10-20 mm), moderate (5-10 mm), and weak $(<5 \mathrm{~mm})^{33}$. Therefore, liquid soap with a $T$. catappa leaves extract concentration of $1 \%, 2 \%, 3 \%$ in the preparation provides a very strong inhibitory power against $S$. aureus, a strong inhibitory power against $S$. 
epidermidis, and moderate inhibition against $E$. coli. This result follows the literature and research objectives that the types of bacteria that could significantly infect the skin were S. aureus and S. epidermidis ${ }^{34}$.

\section{CONCLUSION}

The physical characteristics of $T$. catappa leaves extract liquid soap meets the requirement of SNI 4085:2017 with a $\mathrm{pH}$ value that was safe for the skin. The addition of $T$. catappa leaves extract variations did not affect the $\mathrm{pH}$ value, foam stability, and irritation. However, in the organoleptic test, the higher the concentration of $T$. catappa leaves extract was added, the liquid soap's color was getting more brownish, and the shape form was slightly liquid. The addition of T. catappa leaves extract to liquid soap could increase the antibacterial activity. The highest antibacterial activity was shown by $S$. aureus with an inhibition zone diameter of more than $20 \mathrm{~mm}$.

\section{ACKNOWLEDGMENT}

The authors thank Universitas Abdurrab Foundation for providing research grants. Furthermore, thanks to the Medicine and Health Sciences Faculty, Department of Pharmaceutical and Food Analysis, who have provided facilities for implementing this research. Furthermore, thanks to the students who participated in helping carry out the research.

\section{REFERENCES}

1. Mukhopadhyay P. Cleansers and Their Role in Various Dermatological Disorders. Indian J Dermatol. 2011;56(1):2-6. doi:10.4103/00195154.77542

2. Burton M, Cobb E, Donarchie P, Judah G, Curtis V, Schmidt WP. The Effect of Handwashing with Water or Soap on Bacterial Contamination of Hands. Int J Environ Res Public Health. 2011;8(1):97-104. doi:10.3390/ijerph8010097
3. Jing JLJ, Yi TP, Bose RJC, McCarthy JR, Tharmalingam N, Madheswaran T. Hand Sanitizers: A Review on Formulation Aspects, Adverse Effects, and Regulations. Int J Environ Res Public Health. 2020;17(9):3326. doi:10.3390/ijerph17093326

4. Weatherly LM, Gosse JA. Triclosan Exposure, Transformation, and Human Health Effects. J Toxicol Environ Health B Crit Rev. 2017;20(8):447-69. doi:10.1080/10937404.2017.1399306

5. Allyn OQ Kusumawati E, Nugroho RA. Antimicrobial activity of Terminalia catappa brown leaf extracts against Staphylococcus aureus ATCC 25923 and Pseudomonas aeruginosa ATCC 27853. F1000Res. 2018;7:1406. doi:10.12688/f1000research.15998.1

6. Anand AV, Divya N, Kotti PP. An updated review of Terminalia catappa. Pharmacogn Rev. 2015;9(18):938. doi:10.4103/0973-7847.162103

7. Silva LP, de Angelis CD, Bonamin F, Kushima H, Mininel FJ, Dos Santos LC, et al. Terminalia catappa L.: a medicinal plant from the Caribbean pharmacopeia with anti-Helicobacter pylori and antiulcer action in experimental rodent models. J Ethnopharmacol. 2015;159:285-95. doi:10.1016/j.jep.2014.11.025

8. Nair R, Chanda S. Antimicrobial Activity of Terminalia catappa, Manilkara zapota and Piper betel Leaf Extract. Indian J Pharm Sci. 2008;70(3):390-3. doi:10.4103/0250-474X.43012

9. Ng S, Lasekan O, Muhammad KS, Hussain N, Sulaiman R. Physicochemical properties of Malaysian-grown tropical almond nuts (Terminalia catappa). J Food Sci Technol. 2015;52(10):6623-30. doi:10.1007/s13197-015-1737-z

10. Terças AG, Monteiro ADZ, Moffa EB, Dos Santos JRA, de Sousa EM, Pinto ARB, et al. Phytochemical Characterization of Terminalia catappa Linn. Extracts and Their antifungal Activities against Candida spp. Front Microbiol. 2017;8:595. doi:10.3389/fmicb.2017.00595

11. Tampemawa PV, Pelealu JJ, Kandou FEF. Uji Efektivitas Ekstrak Daun Ketapang (Terminalia catappa L.) Terhadap Bakteri Bacillus amyloliquefaciens. Pharmacon. 2016;5(1):308-20. doi:10.35799/pha.5.2016.11324

12. Widyaningsih S, Chasani M, Diastuti H, Fredyono WN. Liquid Soap from Nyamplung Seed Oil 
(Calophyllum inophyllum L) with Ketapang (Terminalia catappa L) as Antioxidant and Cardamom (Amomum compactum) as Fragrance. Molekul. 2018;13(2):172-9. doi:10.20884/1.jm.2018.13.2.461

13. Divya N, Rengajaran RL, Radhakrishnan R, Allah EFA, Alqarawi AA, Hashem A, et al. Phytotherapeutic efficacy of the medicinal plant Terminalia catappa L. Saudi J Biol Sci. 2019;26(5):9858. doi:10.1016/j.sjbs.2018.12.010

14. Chanda S, Rakholiya K, Nair R. Antimicrobial Activity of Terminalia catappa L. Leaf Extracts against Some Clinically Important Pathogenic Microbial Strains. Chin Med. 2011;2(4):171-7. doi:10.4236/cm.2011.24027

15. Cock IE, Van Vuuren SF. A comparison of the antimicrobial activity and toxicity of six combretum and two terminalia species from southern Africa. Pharmacogn Mag. 2015;11(41):208-18. doi:10.4103/0973-1296.149740

16. Riskitavani DV, Purwani KI. Studi Potensi Bioherbisida Ekstrak Daun Ketapang (Terminalia catappa) terhadap Gulma Rumput Teki (Cyperus rotundus). Jurnal Sains dan Seni ITS. 2013;2(2):E59-63. doi:10.12962/j23373520.v2i2.3593

17. Istarina D, Khotimah S, Turnip M. Aktivitas Antibakteri Ekstrak Metanol Buah Ketapang (Terminalia catappa Linn.) Terhadap Pertumbuhan Staphylococcus epidermidis Dan Salmonella typhi. Protobiont Jurnal Elektronik Biologi. 2015;4(3):98-102. doi:10.26418/protobiont.v4i3.13321

18. Katiki LM, Gomes ACP, Barbieri AME, Pacheco PA, Rodrigues L, Verissimo CJ, et al. Terminalia catappa: Chemical composition, in vitro and in vivo effects on Haemonchus contortus. Ver Parasitol. 2017;246:11823. doi:10.1016/j.vetpar.2017.09.006

19. Sumino, Supriyadi A, Wardiyanto. The Effectiviness of Ketapang (Terminalia cattapa L.) Leave Extract for the Treatment of Aeromonas salmonicida Infection in Catfish (Pangasioniodon hypophthalmus). Jurnal Sain Veteriner. 2013;13(1):79-88. doi:10.22146/jsv.3503

20. Nugroho RA, Manurung H, Nur FM, Prahastika W. Terminalia catappa L. extract improves survival, hematological profile and resistance to Aeromonas hydrophila in Betta sp. Arch Polish Fish. 2017;25(2):103-15. doi:10.1515/aopf-2017-0010
21. Hardhiko RS, Suganda AG, Sukandar EY. Aktivitas antimikroba ekstrak etanol, ekstrak air daun yang dipetik dan daun gugur pohon ketapang (Terminalia cattapa L.). Acta Pharm Indones. 2004;29:129-33.

22. Haro G, Iksen I, Rumanti RM, Marbun N, Sari RP, Gultom RPJ. Evaluation of Antioxidant Activity and Minerals Value from Watercress (Nasturtium officinale R.Br.). Rasayan J Chem. 2018;11(1):232-7. doi:10.7324/RJC.2018.1112011

23. Syahrina S, Asfianti V, Gurning K, Iksen I. Phytochemical Screening and Anti-Hyperuricemia Activity Test In Vivo of Ethanolic Extract of Shallot (Allium cepa L.) Skin. Borneo J Pharn. 2020;3(3):14651. doi:10.33084/bjop.v3i3.1365

24. Muthmainnah R, Rubiyanto D, Julianto TS. Formulasi Sabun Cair Berbahan Aktif Minyak Kemangi Sebagai Antibakteri Dan Pengujian Terhadap Staphylococcus Aureus. IJCR Indones J Chem Res. 2014;1(2):44-50. doi:10.20885/ijcr.vol1.iss2.art6

25. Sasongko H, Mumpuni AS. Pengaruh penambahan sukrosa terhadap mutu sabun transparan dari ekstrak etanol herba pegagan (Centella asiatica L.). Pharmaciana. 2017;7(1):71-8. doi:10.12928/pharmaciana.v7i1.5795

26. Anggraeni Y, Nisa' F, Bertha OS. Karakteristik Fisik dan Aktivitas Antibakteri Sabun Cair Minyak Nilam (Pogostemon cablin Benth.) yang Berbasis Surfaktan Sodium Lauril Eter Sulfat. Jurnal Kefarmasian Indonesia. 2020;10(1):1-10. doi:10.22435/jki.v10i1.499

27. Abu FA, Yusriadi, Tandah MR. Formulasi Sediaan Sabun Cair Antibakteri Minyak Atsiri Daun Kemangi (Ocimumamericanum L.) dan Uji Terhadap Bakteri Staphylococcus epidermidis dan Staphylococcus aureus. Jurnal Farmasi Galenika Galenika J Pharm. 2015;1(1):1-8. doi:10.22487/j24428744.2015.v1.i1.4835

28. Sampaio BL, Edrada-Eel R, Da Costa FB. Effect of the environment on the secondary metabolic profile of Tithonia diversifolia: a model for environmental metabolomics of plants. Sci Rep. 2016;6:29265. doi:10.1038/srep29265

29. Badan Standarisasi Nasional. Sediaan Sabun Cair. SNI 4085:2017. Jakarta, Indonesia: Badan Standarisasi Nasional; 2017.

30. SaputraSA, Lailiyah M, Erivina A. Formulasi Dan Uji Aktivitas Anti Bakteri Masker Gel Peel-Off Ekstrak 
Daun Pacar Air (Impatiens balsamina linn.) Dengan Kombinasi Basis PVA dan HPMC. Jurnal Riset Kefarmasian Indonesia. 2019;1(2):114-22. doi:10.33759/jrki.v1i2.20

31. Balouiri M, Sadiki M, Ibnsouda SK. Methods for in vitro evaluating antimicrobial activity: A review. J Pharm Anal. 2016;6(2):71-9. doi:10.1016/j.jpha.2015.11.005

32. Zeniusa P, Ramadhan MR, Nasution SH, Karima N. Uji Daya HambatEkstrak Etanol Teh Hijau Terhadap Escherichia Coli Secara In Vitro. Med J Lampung Univ Majority. 2019;8(2):136-43.

33. Davis WW, Stout TR. Disc Plate Method of Microbiological Antibiotic Assay: I. Factors Influencing Variability and Error. Appl Microbiol. 1971,22(4):659-65.

34. Otto M. Staphylococcus epidermidis - the "accidental" pathogen. Nat Rev Microbiol. 2009;7(8):555-67. doi:10.1038/nrmicro2182 